\title{
Alkaline fractionation and enzymatic saccharification of wheat dried distillers grains with solubles (DDGS)
}

Article

Accepted Version

Creative Commons: Attribution-Noncommercial-No Derivative Works 4.0

Zaini, N.A.B., Chatzifragkou, A. and Charalampopoulos, D. (2019) Alkaline fractionation and enzymatic saccharification of wheat dried distillers grains with solubles (DDGS). Food and Bioproducts Processing, 118. pp. 103-113. ISSN 0960-3085 doi: https://doi.org/10.1016/j.fbp.2019.09.006 Available at https://centaur.reading.ac.uk/86352/

It is advisable to refer to the publisher's version if you intend to cite from the work. See Guidance on citing.

To link to this article DOI: http://dx.doi.org/10.1016/j.fbp.2019.09.006

Publisher: Elsevier

All outputs in CentAUR are protected by Intellectual Property Rights law, including copyright law. Copyright and IPR is retained by the creators or other copyright holders. Terms and conditions for use of this material are defined in the End User Agreement.

www.reading.ac.uk/centaur 
Central Archive at the University of Reading

Reading's research outputs online 


\section{Alkaline fractionation and enzymatic saccharification of wheat dried distillers grains with solubles (DDGS)}

${ }^{\text {a }}$ Department of Food and Nutritional Sciences, University of Reading, Whiteknights, PO Box

$8{ }^{\mathrm{b}}$ Centre of Biotechnology and Functional Food, Faculty of Science and Technology, Universiti Kebangsaan Malaysia, 43600 Bangi, Selangor, Malaysia

12 "Correspondence concerning this manuscript to Professor Dimitris Charalampopoulos, Department of

13 Food and Nutritional Sciences, University of Reading, e-mail: d.charalampopoulos@ reading.ac.uk 


\section{Abstract}

22 The complete utilisation of Dried Distillers Grains with Soluble (DDGS) requires effective

23 pretreatment strategies aiming to increase the enzymatic digestibility of cellulose and improve its

24 conversion to fermentable sugars. To this end, the effect of different $\mathrm{NaOH}$ concentrations $(0-$

$255 \%, \mathrm{w} / \mathrm{v})$ and temperature $\left(30-121^{\circ} \mathrm{C}\right)$ on the fractionation of DDGS to its main components

26 (cellulose, hemicellulose, proteins) was evaluated. As the $\mathrm{NaOH}$ concentration and temperature

27 increased, the total sugar content of the pretreated DDGS solids progressively increased to a 28 maximum of $\sim 88 \%$. At $121{ }^{\circ} \mathrm{C}$ and $5 \% \mathrm{NaOH}$, the DDGS solid residue consisted primarily of 29 glucose $(\sim 53 \%)$, a 5-fold increase compared to the original DDGS, reflecting the presence of 30 cellulose, and to a lesser extent by xylose $(\sim 25 \%)$ and arabinose $(\sim 10 \%)$ reflecting the presence of 31 hemicellulose. Approximately $83 \%$ of the initial hemicellulose and $79 \%$ of the protein contents

32 were removed into the liquid fraction during alkaline pretreatment. The enzymatic digestibility of 33 the pretreated DDGS solids by the Accellerase ${ }^{\circledR} 1500$ cellulase enzyme was significantly 34 improved, resulting in a 3.6 fold increase in glucose yield compared to untreated DDGS. Mass 35 balance analysis demonstrated that the proposed process scheme recovers the majority of the key 36 DDGS components (cellulose, hemicellulose, proteins) in an efficient manner with relatively low 37 losses, and provides a viable approach for the valorisation of DDGS.

40 Keywords: DDGS, alkaline pretreatment, cellulose, hemicellulose, cellulase 


\section{Introduction}

The production of biofuels and platform chemicals such as bioethanol and organic acids

45 from renewable bioresources is attracting significant attention. Dried Distillers Grains with

46 Solubles (DDGS) is a bioresource that is produced in large amounts worldwide as a by-product

47 from bioethanol and distillery industries. With regards to bioethanol production, approximately

48 one third of every kilogram of wheat or corn is converted into ethanol, one third into carbon dioxide

49 and one third into DDGS (Bruynooghe et al., 2013; Chatzifragkou et al., 2015). In the USA, DDGS

50 from bioethanol plants is corn-based (Moreau et al., 2012), whereas, in the United Kingdom,

51 Canada, and most of European countries, it is wheat based (Burton et al., 2014). DDGS is used as

52 animal feed and is an important source of energy, protein, water-soluble vitamins and minerals for

53 livestock. However, the addition of DDGS to livestock feed can only account for up to $30 \%$ (on a

54 dry matter basis) of the diet, as higher levels may cause palatability and excessive protein

55 consumption issues. Moreover, the variation in the nutritional composition of DDGS, particularly

56 its protein content, depends on the source and the production processes, and is an obstacle for the

57 extensive utilisation of DDGS as animal feed supplement for ruminants (Belyea et al., 2010).

58 Considering the above, as well as the increased bioethanol-derived DDGS availability in future

59 years, it is important to identify higher value alternative ways for the valorisation of DDGS, which

60 support the circular bioeconomy concept.

61 The main components of DDGS include protein, fibre, lipids, minerals and vitamins;

62 compared to the original grain composition, they are concentrated approximately 3-fold in DDGS,

63 as a result of the DDGS production process which consists of a series of concentration steps and a

64 final drying step. In the case of wheat DDGS, the protein derives from wheat (gluten, globulins

65 and albumins) and the yeast cells, as the latter are not separated during the DDGS production 
process (Villegas-Torres et al., 2015). According to Han and Liu (2010), around 20\% of the total

67 protein in corn DDGS is contributed by yeast. From a valorisation perspective, the protein in

68 DDGS can be recovered using chemical extraction methods and could be potentially utilised in

69 food, feed and agricultural applications (Chatzifragkou et al., 2015; Chatzifragkou et al., 2016).

70 Cellulose and hemicellulose are the main carbohydrates in DDGS that can be potentially

71 hydrolysed to monomeric sugars, namely glucose, xylose and arabinose and used as fermentation

72 feedstock (Bals et al., 2006; Xu and Hanna, 2010). However, plant-derived biomass residues

73 including DDGS are known for their rigid structure and reluctance to enzymatic breakdown, which

74 renders the release of fermentable monomeric sugars from such matrices a challenge (Zhao et al.,

75 2012). The main contributors towards the complex and rigid structure of plant biomass are the

76 interactions between lignin, cellulose and hemicellulose as well as the crystallinity of cellulose.

77 Because of the complexity of biomass structure, the hydrolysis of lignocellulosic materials into

78 fermentable sugars constitutes a major bottleneck in biorefining industries. DDGS has the

79 advantage over other agri-food biomass residues and by-products that it contains low amounts of

80 lignin ( $\sim 5 \%$ on a dry basis), which renders the fractionation process considerably easier

81 (Chatzifragkou et al., 2016).

A significant amount of work has demonstrated that for the complete hydrolysis of various

83 agri-food materials, efficient, scalable and cost-effective pretreatment strategies are required to

84 enhance the enzymatic digestibility of the carbohydrates and thus increase their conversion to

85 fermentable sugars (Kim et al., 2016). A number of pretreatment strategies have been investigated

86 for a variety of feedstocks with the focus being on lignocellulosic materials, including dilute acid

87 hydrolysis (Hsu et al., 2010), ammonium fibre expansion (AFEX) (Dien et al., 2008; Kim et al.,

88 2008b), hot water extraction (Kim et al., 2009; Yang et al., 2011), steam explosion (Yang et al., 
2011) and alkaline treatment (Asghar et al., 2015; Kim et al., 2016; Kim et al., 2008a; McIntosh

90 and Vancov, 2011; Subhedar and Gogate, 2014). This has been previously demonstrated for a

91 variety of biomass including soybean straw (Wan et al., 2011), sugarcane bagasse (da Silva et al.,

92 2016; Zhao et al., 2009), switchgrass (Xu et al., 2010), wheat straw (Asghar et al., 2015; Han et

93 al., 2012; McIntosh and Vancov, 2011), barley hull (Kim et al., 2008a), corn stover (Yang et al.,

94 2011) and corn-based DDGS (Dien et al., 2008; Kim et al., 2008b). In this study, the influence of

$95 \mathrm{NaOH}$ concentration, residence time and extraction temperature on the recovery of carbohydrates

96 from wheat DDGS was investigated.

97 Among these pretreatments, the use of alkaline regents is promising as it can alter the

98 degree of polymerization of lignocellulosic components and increase the porosity and surface area

99 of the biomass by solubilising hemicellulose, thus swelling its structure and potentially rendering

100 it more susceptible to subsequent enzymatic saccharification (Chatzifragkou et al., 2015; Wan et

101 al., 2011). Moreover, alkaline pretreatment is relatively simple and scalable, while the method

102 normally uses chemicals such as ammonia, sodium hydroxide $(\mathrm{NaOH})$, sodium carbonate

$103\left(\mathrm{Na}_{2} \mathrm{CO}_{3}\right)$, and calcium hydroxide $\left(\mathrm{CaOH}_{2}\right) . \mathrm{NaOH}$ has attracted more attention as it is one of the

104 strongest base catalysts and has a long history of being used as a reagent to pretreat the

105 lignocellulosic material (Kim et al., 2016). The aim of this study was to investigate the effect of

106 alkaline $(\mathrm{NaOH})$ pretreatment of DDGS on the enzymatic digestibility of its cellulosic and

107 hemicellulosic components and monitor the chemical and physical changes taking place during

108 DDGS alkaline pretreatment, fractionation and subsequent enzymatic hydrolysis. This knowledge

109 is important in order to design effective strategies for the fractionation and hydrolysis of DDGS

110 targeting the production of nutrient-rich fermentation feedstocks. 


\section{2. Materials and Methods}

113 2.1 Raw materials and enzymes

114 Dried Distillers Grains with Solubles (DDGS) was supplied from a UK bioethanol plant

115 (Vivergo, Yorkshire, UK). DDGS was ground into fine powder using a coffee grinder (DeLonghi, 116 Australia), sieved through sieve mesh No. 20 (particle size smaller than $0.85 \mathrm{~mm}$ ) and stored at

117 room temperature $\left(20^{\circ} \mathrm{C}\right)$ prior to analysis. The commercial enzyme, Accellerase ${ }^{\circledR} 1500$ was

118 kindly provided by Danisco US Inc. (Genencor, Leiden, Netherlands) and was stored at $4{ }^{\circ} \mathrm{C}$ until

119 further use. According to the manufacturer's specifications, Accellerase ${ }^{\circledR} 1500$ exerted endo120 glucananase (2200 - $2800 \mathrm{CMC} \mathrm{U/g),} \mathrm{exoglucanase,} \mathrm{hemicellulase} \mathrm{and} \beta$-glucosidase $(450-775$ $121 p \mathrm{NPG} \mathrm{U} / \mathrm{g})$ activities.

\subsection{Composition of DDGS}

The proximate composition (moisture, crude protein, crude fat and ash) of DDGS was

125 determined according to the official methods of the Association of Analytical Communities (1996)

126 (AOAC). The moisture content was determined using the oven-dry method at $105^{\circ} \mathrm{C}$ (overnight)

127 and was expressed as percentage by weight of sample. The dried DDGS was then heated for ash

128 content determination in a muffle furnace at $530{ }^{\circ} \mathrm{C}$ for 4 hours. The protein content was

129 determined using the Kjeldahl method, where DDGS was digested in concentrated sulfuric acid,

$130 \mathrm{H}_{2} \mathrm{SO}_{4}$, followed by distillation and titration with $0.1 \mathrm{~N} \mathrm{H}_{2} \mathrm{SO}_{4}$. The nitrogen content of DDGS

131 was then multiplied by a factor of 5.7 (nitrogen conversion factor for wheat) to calculate the

132 percentage of crude protein. For fat content analysis, petroleum ether was used as the extraction

133 solvent. The extraction was carried out in a Soxhlet apparatus for 4 hours. The solvent was 
134 removed from the extracted fat by evaporation using a rotary evaporator at $60{ }^{\circ} \mathrm{C}$, followed by

135 oven drying at $105^{\circ} \mathrm{C}$ for approximately 1 hour. The percentage fat was calculated on a mass basis

136 compared to the initial sample. The total starch content was quantified using the Megazyme

137 determination kit (K-TSTA 09/14, Megazyme, Ireland).

138 The carbohydrate (cellulose and hemicellulose) content and lignin content of DDGS were

139 determined according to the method by the National Renewable Energy Laboratory (NREL/TP-

140 510-42618), which involves a two-step acid hydrolysis process to hydrolyse polysaccharides to

141 monosaccharides (glucose derived from cellulose, and xylose and arabinose derived from

142 hemicellulose). Acid-soluble lignin was quantified by ultraviolet spectroscopy at $320 \mathrm{~nm}$

143 wavelength, while acid-insoluble lignin was determined gravimetrically after acid hydrolysis

144 (Sluiter et al., 2011). The sugar composition of the acid hydrolysed DDGS samples was determined

145 by high performance liquid chromatography (HPLC) following the protocol described in section

$146 \quad$ 2.5.4.

DDGS was treated with sodium hydroxide $(\mathrm{NaOH})$ at different concentrations $(0,1,3$ and

$1505 \%, w / v)$, temperatures $\left(30,50,70\right.$ and $\left.121^{\circ} \mathrm{C}\right)$ and time $(0.25,0.5$ and $6 \mathrm{~h})$ in $250 \mathrm{ml}$ screw cap

151 glass bottles, using a 1:10 solid to liquid ratio (100 mL of solution). The trials at 30,50 and $70{ }^{\circ} \mathrm{C}$

152 were conducted in a water-bath, with the stirring set at $200 \mathrm{rpm}$, whereas the trial at $121{ }^{\circ} \mathrm{C}$ was

153 carried out in an autoclave (pressure $\sim 16 \mathrm{psi}$ ). After the pretreatment, the material was cooled

154 down to room temperature and centrifuged at 17,105 x g (Heraeus Multifuge X3R, Thermo Fisher,

155 USA) for 20 minutes at $4{ }^{\circ} \mathrm{C}$. The obtained solids were extensively washed with distilled water 
156 until the $\mathrm{pH}$ reached around 8; the $\mathrm{pH}$ was then adjusted between $5-5.5$ using $6 \mathrm{M} \mathrm{HCl}$. Both

157 insoluble and soluble fractions were frozen $\left(-20^{\circ} \mathrm{C}\right)$, freeze-dried for approximately 5 days, and 158 stored in a closed container at room temperature until further analysis.

162 Duran bottles at $50^{\circ} \mathrm{C}$ and $300 \mathrm{rpm}$ for 48 hours. Different ratios of Accellerase ${ }^{\circledR} 1500$ to cellulose

163 (1 ml: 3.3, 0.66, 0.33 and $0.22 \mathrm{~g}$ ) were used to hydrolyse untreated DDGS (30\%, w/v). Samples

164 were collected at several times intervals, heat inactivated at $95{ }^{\circ} \mathrm{C}$ for 10 minutes and centrifuged

165 at $17,105 \times \mathrm{g}$ for 20 minutes $\left(15^{\circ} \mathrm{C}\right)$. The supernatant was kept for sugar analysis, which was

166 conducted by HPLC (see section 2.5.4). The enzyme loading concentration that gave the highest

167 amount of glucose released was selected and tested against alkaline pretreated DDGS.

2.5 Physicochemical characterisation of DDGS

$171 \quad 2.5 .1$ Fourier transform infrared (FTIR) analysis

172 FTIR analysis of untreated and pretreated DDGS solid samples was performed to

173 determine the changes in functional groups caused as a result of the pretreatment process. One

174 gram of dried sample (particle size $<0.85 \mathrm{~mm}$ ) was uniformly spread on the crystal surface area

175 and covered by a flat probe tip. The spectra (10 scans per sample) of both DDGS samples were

176 collected from 4000 to $500 \mathrm{~cm}^{-1}$ at a $4 \mathrm{~cm}^{-1}$ resolution using a benchtop FTIR Spectrometer

177 (Perkin-Elmer Spectrum 100, USA), equipped with a universal attenuated total reflection (ATR) 
178 accessory and the Atmospheric Vapor Compensation (AVC) software, which was used to remove 179 spectral interferences caused by water and carbon dioxide.

$181 \quad$ 2.5.2 X-ray diffraction (XRD) analysis

182 The X-ray diffraction pattern and crystallinity of untreated and pretreated DDGS solid 183 samples was determined by a powdered X-ray diffractometer (Bruker D8 Advance, Germany) at $18440 \mathrm{kV}$ and $40 \mathrm{~mA}$ using $\mathrm{Cu} \mathrm{K} \alpha$ radiation $(\lambda=1.54 \AA)$. The scan range was between $2 \theta=5$ and $65^{\circ}$ 185 with a step size of $0.02^{\circ}$ and the scattered ray beam was detected using a Lynxeye XE detector. 186 The degree of crystallinity $\left(X_{c}\right)$ was calculated as (Binod et al., 2012; Zhou et al., 2005):

$$
X_{c}(\%)=F_{c} /\left(F_{c}+F_{a}\right) \times 100
$$

188 where $F_{c}$ and $F_{a}$ are the areas of the crystalline and non-crystalline region, respectively. 
The sugars composition of DDGS solid samples (untreated, alkaline treated, enzymatically treated) and DDGS hydrolysate were determined by HPLC. An Agilent Infinity 1260 system

201 (Agilent Technologies, USA) was used with an Aminex HPX-87H column (Bio-rad, Hercules, $202 \mathrm{CA}$ ). Analysis was performed at $0.6 \mathrm{ml} / \mathrm{min}$ flow rate, with $5 \mathrm{mM} \mathrm{H}_{2} \mathrm{SO}_{4}$ as mobile phase. The 203 temperature of the column was set at $65{ }^{\circ} \mathrm{C}$ and sugars were detected using a refractive index 204 detector (RID). Quantification of compounds was performed according to external calibration 205 curves using glucose, arabinose, xylose (Sigma Aldrich), cellobiose, xylobiose and xylotriose 206 (Megazyme) as standards.

208 (dried liquid fraction) recovered, and expressed as a percentage of the initial mass. Total mass 209 recovery was calculated by adding up the masses of insoluble solids and soluble material together

210 (Wan et al., 2011). Sugar recovery was calculated by expressing the amount of glucose, xylose or 211 arabinose released in the hydrolysates as a percentage of the amount of each respective sugar in 212 the original DDGS (da Silva et al., 2016).

$214 \quad 2.7$ Statistical Analysis

215 Statistical analysis was conducted using the Minitab®16 statistical analysis software. One216 way analysis of variance (ANOVA) with a Tukey's multiple comparison test was used to 217 determine significant differences between treatments, at a confidence level of 95\% $(\mathrm{P}<0.05)$. 218 Results are presented as mean \pm standard deviation. 


\subsection{Chemical composition of DDGS}

222 The composition of wheat DDGS is presented in Table 1. DDGS contained high amounts of protein 223 and fibre (total of cellulose, hemicellulose and beta-glucans) equal to approximately 28.3 and $22431.4 \%(w / w)$, respectively, whereas the amounts of lignin, lipids and starch were approximately $2252.9,3.4$ and $0.8 \%(\mathrm{w} / \mathrm{w})$, respectively. The low starch content was expected as starch is hydrolysed 226 during the saccharification step during the bioethanol production process. The protein, fibre, fat 227 and mineral contents (ash) were broadly in line with other works reporting the composition of 228 wheat DDGS (Chatzifragkou et al., 2016; Cozannet et al., 2010; Pedersen et al., 2014; Widyaratne 229 and Zijlstra, 2007). In terms of the protein and fat contents, the results obtained in this study are 230 similar with the data reported by Chatzifragkou et al. (Chatzifragkou et al., 2016), who reported $23129 \%$ for protein and $3.4 \%$ for fat. However, higher protein and fat contents were reported by 232 Cozannet et al., (Cozannet et al., 2010) (36\% and 4.6\%, respectively) and Pedersen et al., (Pedersen 233 et al., 2014) (33.4\% and 5.25\%, respectively). In terms of the ash content, this study found similar 234 result (5.6\%, w/w) with Cozannet et al., (Cozannet et al., 2010) (5.2\%) and Widyaratne and Zijlstra 235 (2007) (5.3\%), whereas other studies reported varied ash contents, i.e. 3.9\% (Chatzifragkou et al., 236 2016) and 9.1\% (w/w) (Pedersen et al., 2014). Cellulose (including $\beta$-glucan) and hemicellulose 237 contents of DDGS were approximately 11.1 and $20.3 \%(\mathrm{w} / \mathrm{w})$, respectively. These values are lower 238 than data reported by Chatzifragkou et al., (Chatzifragkou et al., 2016) (15\% cellulose and 25\% 239 hemicellulose). However, lower cellulose (7\%) and higher hemicellulose (42\%) was reported for 240 wheat DDGS derived from a bioethanol plant in western Canada (Nuez Ortín and Yu, 2009). The 241 variation in the nutritional composition of DDGS might be associated with differences in the 242 production processes used by different plants, the type of wheat cultivar, seasonal variation of 
243 harvest and difference in N-to-protein conversion factor (6.25 over 5.7) (Chatzifragkou et al., 244 2016).

245 Table 1: Chemical composition of wheat DDGS

\begin{tabular}{lc}
\hline Component & Composition (\%, w/w dry basis) \\
\hline Moisture & $10.8 \pm 0.1$ \\
Dry matter & $89.2 \pm 0.1$ \\
Crude protein & $28.3 \pm 0.5$ \\
Crude fat & $3.40 \pm 0.04$ \\
Starch & $0.8 \pm 0.2$ \\
*Cellulose (glucose) & $11.1 \pm 0.4$ \\
Hemicellulose & $20.3 \pm 1.7$ \\
Xylose & $13.7 \pm 1.6$ \\
Arabinose & $6.6 \pm 1.9$ \\
Lignin & $2.0 \pm 0.1$ \\
Acid Soluble Lignin & $2.9 \pm 0.1$ \\
Acid Insoluble Lignin & n.d. \\
Ash & $5.64 \pm 0.13$ \\
\hline *It is assumed that all glucose comes from cellulose, though $\beta$-glucans might be also present at small \\
amounts
\end{tabular}

Figure 1 shows the effect of enzyme loading concentration on glucose yield from untreated

252 DDGS. The highest glucose concentration was achieved when DDGS was hydrolysed at a ratio of $2531: 0.22$ (Accellerase ${ }^{\circledR} 1500, \mathrm{ml}: \mathrm{g}$ cellulose) for $24 \mathrm{~h}$, corresponding to a yield of $\sim 26 \%(\mathrm{w} / \mathrm{w})$, 254 although there was no significant difference $(\mathrm{P}<0.05)$ with $1: 0.33$ (Accellerase® $1500, \mathrm{ml}: \mathrm{g}$ 255 cellulose) ratio. Since cellulose exists in both amorphous and crystalline states, the enzymatically 
256 produced glucose was most likely derived from the amorphous state. At this amorphous state 257 cellulose exists in a disordered arrangement, and Accellerase ${ }^{\circledR} 1500$ through its endoglucanase 258 and $\beta$-glucosidase activities was most likely able to selectively hydrolyse it into glucose and 259 cellulo-oligosaccharides, as also shown previously (Gao et al., 2013). In the case of the crystalline 260 state, the cellulose chains are closely packed together by strong intra- and inter- molecular 261 hydrogen bond linkages. Because of these structural characteristics, cellulose digestibility has been 262 reported to be around $20 \%$ or less without any pretreatment steps for cellulosic biomass residues,

263 such as wheat straw and sugarcane bagasse (Bensah and Mensah, 2013; Mosier et al., 2005; Rabelo 264 et al., 2011). Besides glucose, xylose, arabinose and xylo-oligosaccharides (xylobiose and 265 xylotriose) were also detected (data not shown) at the end of the hydrolysis which are due to the 266 hemicellulase activities of Accellerase ${ }^{\circledR}$ 1500. The results obtained with DDGS in this work are 267 in line with previous observations with lignocellulosic materials, indicating that glucose recovery 268 from DDGS by an enzymatic process is limited by the structural characteristics of DDGS.

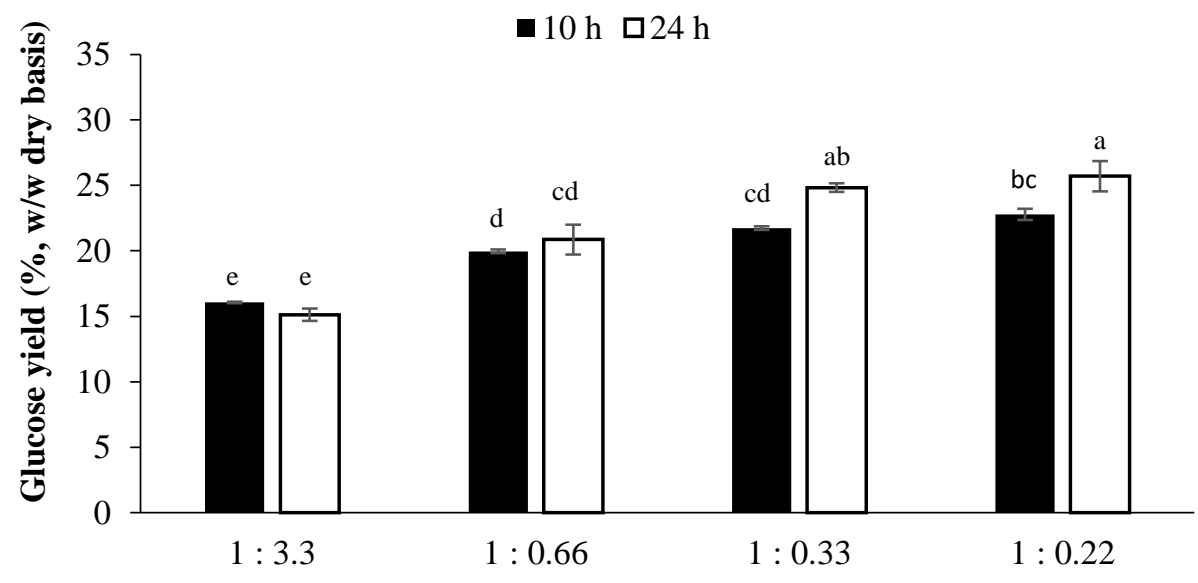

Enzyme loading (Accellerase ${ }^{\circledR}$ 1500, $\mathrm{mL}$ : g cellulose)

270 Figure 1: Effect of different concentrations of Accellerase ${ }^{\circledR} 1500$ enzyme on glucose production from 271 untreated DDGS at $50^{\circ} \mathrm{C}$. Means with different alphabet abcd are significantly $(\mathrm{P}<0.005)$ different (Tukey's 272 multiple range test). 
274 3.3 Alkaline pretreatment of DDGS

275

Table 2 presents the monomeric sugar composition of DDGS solids following

277 pretreatment at various temperatures $\left(30,50,70\right.$ and $\left.121^{\circ} \mathrm{C}\right)$ and $\mathrm{NaOH}$ concentrations $(0,1,3$

278 and 5\%,w/v) and the recoveries of glucose, xylose and arabinose compared to the original DDGS

279 sample. When DDGS was treated with water at $30,50,70$ and $121^{\circ} \mathrm{C}$ the total concentrations of

280 glucose, xylose and arabinose in the residual solids ranged from 38 - 42\% (w/w) with the

281 recoveries (compared to untreated DDGS) being $70-90 \%(\mathrm{w} / \mathrm{w})$. This finding suggests that the

282 majority of hemicellulose was not extracted from the DDGS solids (reflected by the high recovery

283 of xylose and arabinose in the DDGS solids) and that if water was to be used for the pretreatment

284 of DDGS, temperatures higher than $121^{\circ} \mathrm{C}$ would most likely be needed in order to breakdown

285 the cellulose bonds and solubilise hemicellulose. Pisupati and Tchapda (2015) reported that

286 hemicellulose bonds breakdown at $150-230{ }^{\circ} \mathrm{C}$, while significantly higher temperatures are

287 required for cellulose breakdown $\left(300\right.$ to $\left.350{ }^{\circ} \mathrm{C}\right)$.

288

289

290

291

292

293

294 


\begin{tabular}{|c|c|c|c|c|c|c|c|c|c|}
\hline \multirow{2}{*}{ 窇 } & \multirow{2}{*}{ 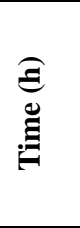 } & \multirow{2}{*}{ 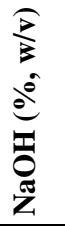 } & \multicolumn{4}{|c|}{$\begin{array}{l}\text { Sugar content in pretreated solids } \\
(\%, w / w \text { dry basis })\end{array}$} & \multicolumn{3}{|c|}{$\begin{array}{l}\text { Sugar recovery in pretreated solids } \\
(\%, \mathrm{w} / \mathrm{w} \text { dry basis }) *\end{array}$} \\
\hline & & & Glucose & Xylose & Arabinose & Total & Glucose & Xylose & Arabinose \\
\hline \multirow[t]{4}{*}{30} & \multirow[t]{4}{*}{6} & 0 & $13.4 \pm 0.8^{\mathrm{gh}}$ & $19.0 \pm 1.4$ & $9.9 \pm 0.3$ & 42.3 & $73.6 \pm 4.2^{\mathrm{a}}$ & $83.9 \pm 6.0$ & $90.2 \pm 3.0$ \\
\hline & & 1 & $14.7 \pm 0.2^{\text {fgh }}$ & $18.8 \pm 0.1$ & $9.6 \pm 0.4$ & 43.1 & $63.9 \pm 2.6^{b}$ & $65.9 \pm 1.9$ & $69.6 \pm 5.1$ \\
\hline & & 3 & $17.4 \pm 0.4^{\mathrm{fgh}}$ & $18.5 \pm 0.1$ & $9.5 \pm 0.8$ & 45.4 & $53.7 \pm 1.3^{c}$ & $45.6 \pm 0.2$ & $48.9 \pm 4.3$ \\
\hline & & 5 & $20.0 \pm 1.4^{\mathrm{f}}$ & $14.4 \pm 1.0$ & $9.6 \pm 0.2$ & 44.0 & $47.7 \pm 1.1^{\mathrm{cd}}$ & $27.6 \pm 0.7$ & $38.2 \pm 2.8$ \\
\hline \multirow[t]{4}{*}{50} & \multirow[t]{4}{*}{6} & 0 & $13.3 \pm 0.0^{g h}$ & $18.7 \pm 0.0$ & $9.1 \pm 0.0$ & 41.1 & $73.3 \pm 0.3^{\mathrm{a}}$ & $82.8 \pm 0.4$ & $83.3 \pm 0.4$ \\
\hline & & 1 & $18.0 \pm 0.1^{\text {fgh }}$ & $19.4 \pm 0.1$ & $8.2 \pm 0.1$ & 45.6 & $62.5 \pm 1.2^{b}$ & $54.3 \pm 0.6$ & $47.7 \pm 0.5$ \\
\hline & & 3 & $27.6 \pm 0.9^{e}$ & $25.2 \pm 0.2$ & $8.9 \pm 0.0$ & 61.7 & $50.8 \pm 1.8^{\mathrm{cd}}$ & $37.2 \pm 0.4$ & $27.4 \pm 0.1$ \\
\hline & & 5 & $34.0 \pm 0.5^{\mathrm{cd}}$ & $18.9 \pm 0.6$ & $9.7 \pm 0.6$ & 62.6 & $45.6 \pm 0.02^{d}$ & $20.4 \pm 0.3$ & $21.7 \pm 0.9$ \\
\hline \multirow[t]{4}{*}{70} & \multirow[t]{4}{*}{6} & 0 & $13.2 \pm 0.2^{\mathrm{gh}}$ & $17.9 \pm 0.4$ & $9.3 \pm 0.5$ & 40.4 & $72.5 \pm 0.04^{a}$ & $78.7 \pm 0.6$ & $84.7 \pm 3.1$ \\
\hline & & 1 & $28.3 \pm 1.3^{\mathrm{de}}$ & $25.2 \pm 0.6$ & $9.6 \pm 0.5$ & 63.2 & $64.9 \pm 3.4^{b}$ & $46.4 \pm 0.9$ & $36.6 \pm 1.7$ \\
\hline & & 3 & $35.3 \pm 0.8^{c}$ & $29.9 \pm 0.2$ & $10.2 \pm 0.6$ & 75.4 & $48.6 \pm 1 .^{\mathrm{cd}}$ & $33.2 \pm 04$ & $23.3 \pm 1.4$ \\
\hline & & 5 & $44.7 \pm 2.2^{b}$ & $21.8 \pm 0.8$ & $10.8 \pm 0.3$ & 77.2 & $47.1 \pm 1.1^{\mathrm{cd}}$ & $18.4 \pm 0.2$ & $18.9 \pm 0.02$ \\
\hline \multirow{5}{*}{$\begin{array}{c}121 \\
\text { (16 psi) }\end{array}$} & \multirow[t]{5}{*}{0.25} & 0 & $13.5 \pm 0.2^{\mathrm{gh}}$ & $18.3 \pm 0.3$ & $10.6 \pm 0.1$ & 42.4 & $68.4 \pm 0.5^{a b}$ & $74.3 \pm 0.8$ & $89.2 \pm 0.7$ \\
\hline & & 0.5 & $18.6 \pm 0.7^{\mathrm{fg}}$ & $21.2 \pm 0.2$ & $10.1 \pm 0.02$ & 49.9 & $62.9 \pm 2.2^{b}$ & $57.4 \pm 0.3$ & $56.9 \pm 0.4$ \\
\hline & & 1 & $29.5 \pm 0.4^{\text {cde }}$ & $29.7 \pm 0.3$ & $9.7 \pm 0.2$ & 69.0 & $50.7 \pm 0.04^{\mathrm{cd}}$ & $40.9 \pm 1.1$ & $28.2 \pm 0.1$ \\
\hline & & 3 & $43.8 \pm 0.8^{b}$ & $31.5 \pm 2.4$ & $10.59 \pm 0.3$ & 85.9 & $46.8 \pm 0.5^{\mathrm{cd}}$ & $27.0 \pm 1.9$ & $18.9 \pm 0.4$ \\
\hline & & 5 & $52.6 \pm 0.7^{a}$ & $25.0 \pm 0.2$ & $10.34 \pm 0.1$ & 87.9 & $44.7 \pm 1.1^{d}$ & $17.1 \pm 0.8$ & $14.7 \pm 0.7$ \\
\hline \multirow{5}{*}{$\begin{array}{c}121 \\
\text { (16 psi) }\end{array}$} & \multirow[t]{5}{*}{0.5} & 0 & $12.7 \pm 0.2^{h}$ & $17.0 \pm 0.5$ & $8.17 \pm 0.04$ & 37.8 & $64.1 \pm 0.6^{b}$ & $69.3 \pm 2.2$ & $70.0 \pm 0.1$ \\
\hline & & 0.5 & $17.4 \pm 1.6^{\mathrm{fgh}}$ & $19.9 \pm 1.4$ & $8.40 \pm 0.4$ & 45.7 & $62.3 \pm 2.6^{b}$ & $57.4 \pm 1.2$ & $50.4 \pm 5.1$ \\
\hline & & 1 & $27.9 \pm 1.0^{\mathrm{e}}$ & $28.7 \pm 1.4$ & $7.99 \pm 0.5$ & 64.7 & $49.0 \pm 1.4^{\mathrm{cd}}$ & $40.5 \pm 1.6$ & $23.4 \pm 1.3$ \\
\hline & & 3 & $41.1 \pm 1.0^{b}$ & $30.0 \pm 1.8$ & $10.01 \pm 0.02$ & 81.2 & $47.0 \pm 1.5^{\mathrm{cd}}$ & $27.6 \pm 1.3$ & $19.1 \pm 1.0$ \\
\hline & & 5 & $45.4 \pm 5.2^{b}$ & $21.8 \pm 1.6$ & $9.47 \pm 0.3$ & 76.6 & $44.4 \pm 1.0^{d}$ & $17.1 \pm 1.1$ & $15.5 \pm 1.7$ \\
\hline
\end{tabular}

296 Data reported as an average of two replicates

$297 *$ Sugar recovery is calculated as the \% of a particular sugar compared to its content in untreated DDGS

298 Means within each vertical line with different alphabet ${ }^{\text {abcdefgh }}$ are significantly $(\mathrm{P}<0.05)$ different

As the $\mathrm{NaOH}$ increased from 0.5 to $5.0 \%$ and the temperature from 30 to $121^{\circ} \mathrm{C}$ (16 psi)

301 the total sugar content of the pretreated DDGS solids progressively increased, from around $\sim 45 \%$

302 to a maximum of $\sim 88 \%$ in the case of $121{ }^{\circ} \mathrm{C}(\sim 16 \mathrm{psi})$, with $5 \% \mathrm{NaOH}$ for 15 minutes. Glucose

303 was in all cases the main sugar component, reflecting the significant presence of cellulose in the

304 pretreated DDGS solids, as opposed to arabinose and xylose, which reflected the hemicellulose 
content. In the case of the treatment at $121{ }^{\circ} \mathrm{C}$ with $5 \% \mathrm{NaOH}$, the glucose content of the DDGS

306 solids was $\sim 53 \%$, a 5-fold increase compared to the glucose content of the original DDGS, whereas

307 the xylose content was $\sim 25 \%$ and the arabinose $\sim 10 \%$. Alkaline pretreatment causes the

308 solubilisation of hemicelluloses by disrupting the ester and ether bond of hemicellulose with lignin

309 and cellulose microfibrils (Kim et al., 2016; McIntosh and Vancov, 2011). For this reason, and in

310 line with the results in this study, the glucose concentration in the recovered solids has been shown

311 to significantly increase in the case of alkaline pretreatment of lignocellulosic materials such as

312 wheat straw and sugarcane bagasse (Barman et al., 2012; da Silva et al., 2016; McIntosh and

313 Vancov, 2011). Moreover, the increase in cellulose and decrease in the hemicellulose of the

314 pretreated DDGS solids was accompanied by a significant decrease in their protein content, which

315 were solubilised and extracted in the liquid fraction (data not shown). It has been previously shown

316 that under ethanol-alkali conditions $(0.1 \mathrm{M})$, approximately $39.5 \%$ and $49.1 \%$ of the protein

317 (primarily gliadin and glutenin) was extracted from wheat DDGS and wet distiller's grains,

318 respectively (Chatzifragkou et al., 2016). Similarly, approximately $40 \%$ protein was extracted with

$3191 \mathrm{M} \mathrm{NaOH}$ from corn wet distillers grains at $70{ }^{\circ} \mathrm{C}$ (Bals et al., 2009).

320 Taking into account the sugar recovery data presented in Table 2, it can be deduced that

321 alkaline pretreatment selectively removed hemicelluloses over cellulose from DDGS solids. To

322 this end, as the $\mathrm{NaOH}$ concentration increased from $0.5 \%$ to $5 \%$, in all treatment temperatures, the

323 recovery of xylose and arabinose in the pretreated solids progressively decreased; the lowest

324 hemicellulose recovery was obtained after treatment with $5 \% \mathrm{NaOH}$ at the highest temperature,

$325121{ }^{\circ} \mathrm{C}$, with recoveries of $\sim 17 \%$ for xylose and $\sim 15 \%$ for arabinose. This is due to the fact that

326 hemicellulose exists in an amorphous state, as heterogeneous and branched polysaccharides, which

327 makes them more susceptible to alkaline action. The alkali reagent solubilises hemicellulose by 
328 disrupting the ester linkage of hydroxycinnamic acid and the arabinose units present in the 329 arabinoxylan molecules as well as and the linkage of the hydroxyl groups in lignin (Dodd and 330 Cann, 2009; Xu et al., 2010). Interestingly, in terms of glucose recovery in the DDGS pretreatment 331 solids, which reflects cellulose recovery, it was observed that as the $\mathrm{NaOH}$ increased from 0 to $5 \%$ 332 the glucose gradually decreased at all temperatures. More specifically, at $70{ }^{\circ} \mathrm{C}$, glucose recovery 333 decreased from $\sim 73 \%$ (no $\mathrm{NaOH})$ to $\sim 47 \%(5 \% \mathrm{NaOH})$, whereas at $121{ }^{\circ} \mathrm{C}$, glucose recovery 334 decreased from $\sim 68 \%$ (no $\mathrm{NaOH})$ to $\sim 45 \%(5 \% \mathrm{NaOH})$, a phenomenon that will be discussed later 335 on. In order to investigate in more detail the effect of the process on the recoveries of 337 cellulose and hemicellulose, a total mass and sugar recovery balance was conducted, as shown in

338 Table 3. Even with no $\mathrm{NaOH}$ being added, the extraction process carried out at temperatures from 33930 to $121^{\circ} \mathrm{C}$, extracted between 23 to $30 \%$ of soluble material from DDGS. This probably denotes 340 the solubilisation of readily water soluble compounds that are found in DDGS, which are derived 341 from the condensed distillers soluble (CDS) fraction that is commonly mixed with wet solids prior 342 to drum drying during DDGS production process, and may include soluble proteins, organic acids 343 and minerals (Bruynooghe et al., 2013; Liu, 2011). As the $\mathrm{NaOH}$ concentration increased, the mass 344 of the liquid fraction increased due to the solubilisation of hemicelluloses and protein. However, 345 the total mass balance, for both solid and liquid fractions, was not $100 \%$, which could be attributed 346 partly to differences in the moisture content of the dried solid $(\sim 2 \%)$ and dried liquid fractions $347(\sim 2 \%)$, compared to the initial moisture content of untreated DDGS $(\sim 11 \%)$. Moreover, there is 348 also a possibility that some organic compounds such as hydroxymethyl furfural (HMF), aldehydes, 349 glycerol or short chain fatty acids such as lactic acid, which were originally present in DDGS, 
350 decomposed to their gas state during alkaline pretreatment at high temperatures (Yin and Tan, $3512012)$.

352 Table 3: Overall mass recovery and total sugar in pretreated DDGS solids *

\begin{tabular}{|c|c|c|c|c|c|c|c|c|}
\hline \multirow{2}{*}{ 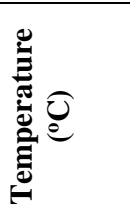 } & \multirow{2}{*}{$\begin{array}{l}\underset{\Xi}{\Xi} \\
\stackrel{\Xi}{\Xi}\end{array}$} & \multirow{2}{*}{ 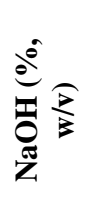 } & \multicolumn{3}{|c|}{$\begin{array}{c}\text { Mass recovery of pretreated DDGS } \\
\text { (\% of initial weight) }\end{array}$} & \multicolumn{3}{|c|}{ Total sugar recovery $(\%)^{* * *}$} \\
\hline & & & Solid & Liquid & Total & Glucose & Xylose & Arabinose \\
\hline \multirow[t]{4}{*}{30} & 6 & 0 & $60.4 \pm 0.1$ & $23.6 \pm 0.1$ & 83.9 & $86.8 \pm 3.8^{\mathrm{ab}}$ & $104.3 \pm 5.5$ & $113.4 \pm 2.9$ \\
\hline & & 1 & $48.0 \pm 1.5$ & $33.7 \pm 0.3$ & 81.7 & $82.2 \pm 2.4^{\mathrm{abc}}$ & $101.9 \pm 1.2$ & $112.9 \pm 5.7$ \\
\hline & & 3 & $33.9 \pm 0.1$ & $39.1 \pm 0.7$ & 73.0 & $80.4 \pm 2.6^{\mathrm{bcd}}$ & $98.5 \pm 0.2$ & $107.6 \pm 5.7$ \\
\hline & & 5 & $26.4 \pm 2.5$ & $49.4 \pm 1.5$ & 75.7 & $82.0 \pm 2.1^{\mathrm{abc}}$ & $99.4 \pm 2.4$ & $115.9 \pm 7.1$ \\
\hline \multirow[t]{4}{*}{50} & 6 & 0 & $60.6 \pm 0.3$ & $26.5 \pm 0.1$ & 87.1 & $87.3 \pm 0.02^{\mathrm{a}}$ & $101.9 \pm 0.3$ & $109.1 \pm 1.2$ \\
\hline & & 1 & $38.3 \pm 0.6$ & $46.2 \pm 2.1$ & 84.4 & $77.0 \pm 1.3^{\mathrm{cd}}$ & $97.2 \pm 1.1$ & $110.5 \pm 1.9$ \\
\hline & & 3 & $20.3 \pm 0.1$ & $58.0 \pm 0.1$ & 78.2 & $75.2 \pm 0.1^{\mathrm{d}}$ & $99.8 \pm 2.5$ & $119.8 \pm 3.9$ \\
\hline & & 5 & $14.8 \pm 0.2$ & $67.9 \pm 0.1$ & 82.7 & $78.8 \pm 1.8^{\mathrm{cd}}$ & $103.4 \pm 0.9$ & $132.7 \pm 6.2$ \\
\hline \multirow[t]{4}{*}{70} & 6 & 0 & $60.3 \pm 0.9$ & $26.9 \pm 0.6$ & 87.2 & $87.6 \pm 0.4^{\mathrm{a}}$ & $99.1 \pm 1.0$ & $109.7 \pm 2.6$ \\
\hline & & 1 & $25.2 \pm 0.1$ & $56.9 \pm 0.1$ & 82.1 & $76.6 \pm 2.8^{\mathrm{cd}}$ & $91.3 \pm 0.6$ & $105.5 \pm 3.9$ \\
\hline & & 3 & $15.2 \pm 0.1$ & $67.3 \pm 0.0$ & 82.5 & $66.5 \pm 2.3^{\mathrm{ef}}$ & $91.4 \pm 3.5$ & $99.4 \pm 5.2$ \\
\hline & & 5 & $11.6 \pm 0.3$ & $77.7 \pm 0.5$ & 89.3 & $67.1 \pm 1.2^{\mathrm{e}}$ & $88.7 \pm 4.8$ & $100.9 \pm 5.0$ \\
\hline \multirow{5}{*}{$\begin{array}{c}121 \\
\text { (16 psi) }\end{array}$} & 0.25 & 0 & $55.7 \pm 0.2$ & $27.0 \pm 0.1$ & 82.6 & $87.1 \pm 0.7^{\mathrm{a}}$ & $102.4 \pm 1.2$ & $117.9 \pm 1.5$ \\
\hline & & 0.5 & $37.1 \pm 2.1$ & $43.9 \pm 0.2$ & 81.0 & $77.0 \pm 1.8^{\mathrm{cd}}$ & $101.1 \pm 0.2$ & $114.6 \pm 0.7$ \\
\hline & & 1 & $18.9 \pm 0.3$ & $56.3 \pm 1.7$ & 75.2 & $61.5 \pm 0.1^{\mathrm{ef}}$ & $90.0 \pm 2.4$ & $110.3 \pm 1.6$ \\
\hline & & 3 & $11.8 \pm 0.1$ & $75.9 \pm 1.0$ & 87.6 & $66.1 \pm 0.5^{\mathrm{ef}}$ & $96.3 \pm 0.04$ & $114.7 \pm 1.2$ \\
\hline & & 5 & $9.4 \pm 0.4$ & $82.0 \pm 0.1$ & 91.3 & $66.2 \pm 1.2^{\mathrm{ef}}$ & $94.0 \pm 6.8$ & $116.6 \pm 2.4$ \\
\hline \multirow{5}{*}{$\begin{array}{c}121 \\
(16 \mathrm{psi})\end{array}$} & 0.5 & 0 & $55.8 \pm 0.2$ & $30.6 \pm 0.4$ & 86.4 & $87.1 \pm 0.6^{\mathrm{a}}$ & $104.9 \pm 3.9$ & $110.6 \pm 6.1$ \\
\hline & & 0.5 & $39.6 \pm 2.1$ & $41.8 \pm 1.7$ & 81.4 & $77.4 \pm 1.1^{\mathrm{cd}}$ & $97.4 \pm 2.5$ & $104.2 \pm 2.8$ \\
\hline & & 1 & $19.3 \pm 0.1$ & $59.3 \pm 0.3$ & 78.6 & $60.0 \pm 1.0^{f}$ & $88.4 \pm 1.0$ & $99.4 \pm 0.1$ \\
\hline & & 3 & $12.6 \pm 0.7$ & $72.6 \pm 3.1$ & 85.1 & $64.1 \pm 0.9^{\mathrm{ef}}$ & $90.3 \pm 5.9$ & $104.9 \pm 9.3$ \\
\hline & & 5 & $10.9 \pm 1.5$ & $72.6 \pm 0.3$ & 83.5 & $65.8 \pm 0.1^{\mathrm{ef}}$ & $91.6 \pm 1.5$ & $110.1 \pm 3.0$ \\
\hline
\end{tabular}

$353 *$ Data reported as an average of two replicate

$354 * *$ Total sugar recovery is calculated as the \% of a particular sugar in both the solid and liquid fractions compared to 355 its content in untreated DDGS

356 Means within each vertical line with different alphabet abcdef are significantly $(\mathrm{P}<0.05)$ different 
361 obvious losses for these compounds during the alkaline pretreatment process. The inconsistency

362 in arabinose and xylose recovery (> 100\%) might due to the variations in the moisture content of

363 dry solid samples, compared to the initial moisture content of untreated DDGS, as previously

364 mentioned. In contrast, considerable glucose losses were noted, especially as the temperature

365 progressively increased from $30^{\circ} \mathrm{C}$ to $121{ }^{\circ} \mathrm{C}$. The highest losses were detected when DDGS was

366 treated with $5 \% \mathrm{NaOH}$ at $121{ }^{\circ} \mathrm{C}$, and ranged from $30 \%$ to $40 \%$. A comprehensive review by Knill

367 and Kennedy (2003) suggested that the degradation of glucose during exposure to alkaline reagents

368 such as $\mathrm{NaOH}, \mathrm{CaCO}_{3}$ and $\mathrm{KOH}$ leads to the production of various compounds including formic

369 acid, acetic acid, hydroxyactic acid, 2-hydroxy-propanoic acid, butyric acid, 2-hydroxybutanoic

370 acid, 3-deoxy-D-pentonic acid, $\beta$-D-glucoisaccharinic acid, D-gluconic acid and D-mannoic acid.

371 End-wise degradation and alkaline scissions are the main mechanisms contributing to glucose

372 losses during alkaline pretreatment. In end-wise degradation (or peeling), glucose loses are due to

373 the dissolution of short chain material, which detaches from the reducing end of cellulose, and

374 results in the formation of 3-deoxy-2-C-(hydroxymethyl)-erythro and thereo-pentonic acids (D-

375 glucoisosaccharinic acids). This mechanism normally occurs at temperatures less than $170{ }^{\circ} \mathrm{C}$. On

376 the other hand, alkaline scission (or hydrolysis) normally occurs at higher temperatures $\left(>170{ }^{\circ} \mathrm{C}\right)$,

377 where random hydrolysis of the glycosidic linkages takes place, and results in significant weight

378 losses and decreases in the degree of polymerisation of cellulose (Knill and Kennedy, 2003). These

379 reactions have also been suggested in other works, where it was shown that during alkaline

380 pretreatment of lignocellulosic biomass at high temperatures, cellulose was converted into

381 dissolved organic compounds such as dihydroxy and dicarboxylic acids, aldehydes, furfural or

382 1,2,3-benzenetriol (Jönsson and Martín, 2016; Yin and Tan, 2012). 
The DDGS solid residues obtained after the alkaline pretreatment conditions which demonstrated the highest total sugar content $\left(5 \% \mathrm{NaOH}, 121^{\circ} \mathrm{C}, 15 \mathrm{~min}\right)$ were then subjected to 387 enzymatic hydrolysis using Accellerase ${ }^{\circledR} 1500$ (

). It was noted that glucose release was significantly higher when the pretreated DDGS

389 solids were hydrolysed with the enzyme compared to untreated DDGS ( $86 \%$ vs 25\%, respectively).

390 This study demonstrated that pretreatment is an important step in improving cellulose digestibility

391 of DDGS. Similar findings were also reported by Xu et al., (Xu et al., 2010) who compared the

392 effect of alkaline pretreatment on switchgrass and showed that the yield of total reducing sugars

393 increased 3.78 times compared to untreated switchgrass. Alkaline pretreatment is known to cause

394 a swelling effect due to the solvation and saponification of hemicelluloses, thus it results in

395 increased porosity and loosening of the structure of DDGS. Therefore, the surface area of cellulose

396 is increased and is more exposed to enzymatic hydrolysis (Han et al., 2012; Kim and Han, 2012).

398 Table 4: Enzymatic hydrolysis of untreated and pretreated DDGS solids at $1: 0.33$ (Accellerase ${ }^{\circledR}$ $3991500, \mathrm{~mL}: \mathrm{g}$ cellulose) ratio for $24 \mathrm{~h}$ at $50^{\circ} \mathrm{C}$

\begin{tabular}{lcccc}
\hline Conditions & \multicolumn{2}{c}{ Monosaccharides (g/L) in the hydrolysate } & Glucose Yield (\%) \\
\cline { 2 - 4 } & Glucose & Xylose & Arabinose & \\
\hline No pretreatment & $8.2 \pm 0.1$ & $10.8 \pm 0.0$ & $1.7 \pm 0.0$ & 24.8 \\
& & & & \\
$\mathbf{5 \%} \mathbf{~ N a O H ~}\left(\mathbf{1 2 1}^{\circ} \mathbf{C}, \mathbf{- 1 6} \mathbf{~ p s i}, \mathbf{1 5} \mathbf{~ m i n}\right)$ & $28.5 \pm 0.6$ & $6.2 \pm 0.2$ & $0.6 \pm 0.0$ & \\
\hline
\end{tabular}


Accellerase ${ }^{\circledR} 1500$ has side activities, including hemicellulase and $\beta$-glucosidase activities,

402 as demonstrated by the considerable amounts of xylose and arabinose released into the 403 hydrolysate. The concentration of xylose and arabinose in the hydrolysate after alkaline 404 pretreatment was lower than in the case of untreated DDGS solids due to the significant removal 405 of hemicelluloses during alkaline treatment. However, the pretreated DDGS solids still contained $406 \sim 25 \%$ of xylose and $\sim 10 \%$ of arabinose (Table 2 ), which are important to be released during 407 enzyme hydrolysis through the action of hemicellulases in order to enhance glucose release. 408 Enzyme cocktails that have, in addition to cellulase, hemicellulase activity, can facilitate glucose 409 release from DDGS and lignocellulosic biomass, as shown for pretreated corn stover (Hu et al., 410 2011). Hemicellulases remove the xylan coat at the surface of the pretreated fibre and thus increase 411 the accessibility of cellulase to the cellulosic fibre (Kumar and Wyman, 2009). Interestingly, 412 hemicellulases such as xylanases, were also shown to significantly improve the cellulose 413 hydrolysis of steam pretreated softwood by cellulases, regardless of the fact that this material did 414 not contain xylan; this was due to the synergistic interaction between cellulase and xylanase, which 415 changed the gross fibre characteristics of softwood (Hu et al., 2011).

416 Figure 1 shows the time course of the enzymatic hydrolysis of the alkaline pretreated 417 DDGS solids, at $50{ }^{\circ} \mathrm{C}$. In addition to glucose, xylose and arabinose, some oligosaccharides were 418 also detected, including xylobiose and xylotriose. Interestingly, cellobiose was not detected. The 419 absence of cellobiose suggests that the activity of exo-glucanase and/or $\beta$-glucosidase in 420 Accellerase ${ }^{\circledR} 1500$ was high, which resulted in the conversion of cellobiose and possibly other 421 gluco-oligosaccharides to glucose. Borges et al., (Borges et al., 2014) reported a value of 228 $422 \mathrm{U} / \mathrm{mL}$ of $\beta$-glucosidase activity in Accellerase ${ }^{\circledR} 1500$ when cellobiose was used as a substrate. As 423 shown in Figure 2, within 6 hours of hydrolysis, approximately $25 \mathrm{~g} / \mathrm{L}$ of glucose, $6 \mathrm{~g} / \mathrm{L}$ of 
424 xylobiose, $5 \mathrm{~g} / \mathrm{L}$ of xylose, $1.3 \mathrm{~g} / \mathrm{L}$ of xylotriose and $\sim 0.6 \mathrm{~g} / \mathrm{L}$ of arabinose were produced. Further 425 increase in hydrolysis time resulted in a slow increase in glucose concertation, reaching a 426 maximum of $\sim 29 \mathrm{~g} / \mathrm{L}$ after $30 \mathrm{~h}$ of hydrolysis. During the same period, the concentration of 427 xylotriose and xylobiose decreased with a concomitant increase in xylose, which reached 7.5 g/L 428 after $30 \mathrm{~h}$. It is most likely that xylobiose and xylotriose were produced through the activities of 429 endo-xylanases present in Accelerase ${ }^{\circledR} 1500$, whereas xylose, through the activity of beta430 xylosidase, which hydrolyses xylobiose to xylose (Badhan et al., 2014).

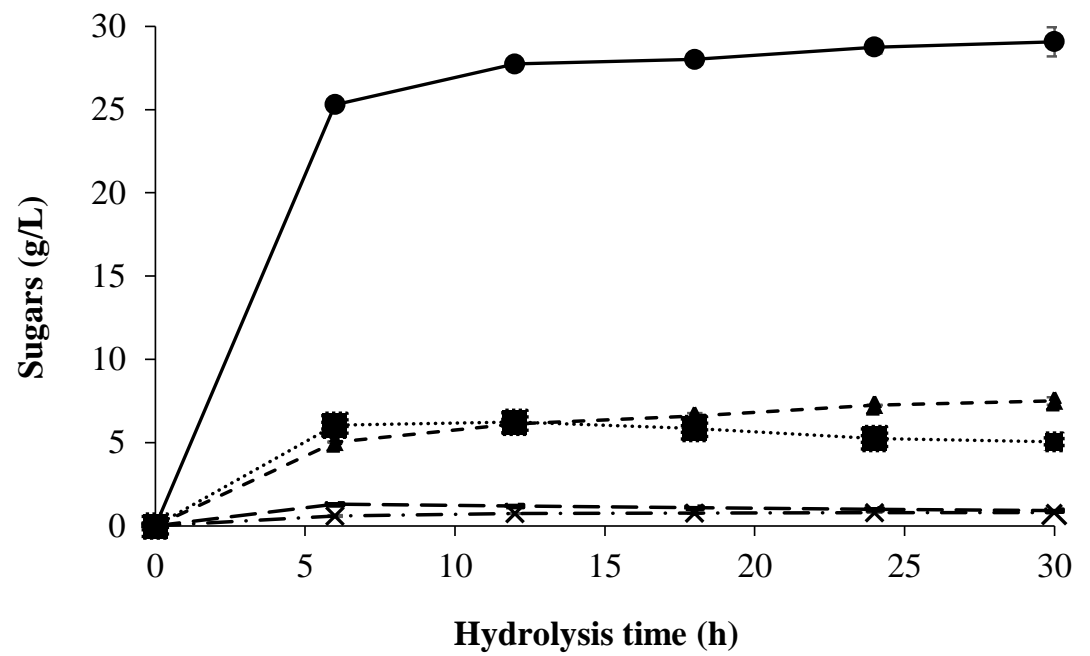

432

433 Figure 2: Time course of sugars released during enzymatic hydrolysis of pretreated DDGS solids $\left(121^{\circ} \mathrm{C}\right.$, $434 \sim 16$ psi, 15 minutes, 5\% NaOH) at $1: 0.33$ (Accellerase ${ }^{\circledR} 1500, \mathrm{~mL}: \mathrm{g}$ cellulose) ratio, (- - ) xylotriose, $435(\cdots \cdots \cdots)$ xylobiose, $(-\infty)$ glucose, $(\cdot-\bullet)$ xylose and $(-\times-)$ arabinose. No cellobiose was detected. 
3.5 Physicochemical characterisation of untreated and pretreated DDGS

3.5.1 Morphological surface of DDGS

The surface of untreated and alkali treated DDGS was observed using ESEM to identify

445 possible structural changes. The intact, compact and rigid surface structure of untreated DDGS

446 (Figure 3a) changed into a fully exposed, separated and peeled-off surface in the alkali treated

447 DDGS (Figure 3c). According to Bensah and Mensah (2013) alkaline pretreatment loosens the

448 structure of biomass, hydrolyses lignin and carbohydrate bonds and decreases the degree of

449 polymerisation and crystallinity of cellulose. Moreover, it also causes the enlargement of the

450 internal surface area of biomass, thus it increases the access of cellulase to the cellulose present in

451 the biomass (Chen et al., 2013; Xu et al., 2010). Previous studies with sugarcane bagasse (Binod

452 et al., 2012) and wheat straw (Asghar et al., 2015) reported that alkaline pretreatment caused the

453 formation of pores on the biomass surface, an effect that was not observed in our study though.

454 When untreated DDGS solids were hydrolysed with Accellerase ${ }^{\circledR} 1500$, the changes to the 455 structure were not profound (Figure 3b). It seems that the enzyme was not able to penetrate the 456 rigid structure of the untreated DDGS cell wall, a fact that can further explain the low enzymatic 457 release of glucose (Table 1). In contrast, the Accellerase ${ }^{\circledR} 1500$ pretreated (with alkali) DDGS 458 solids demonstrated a less rigid structure that was broken into small pieces, indicating the 459 disruption of biomass (Figure 3d). 


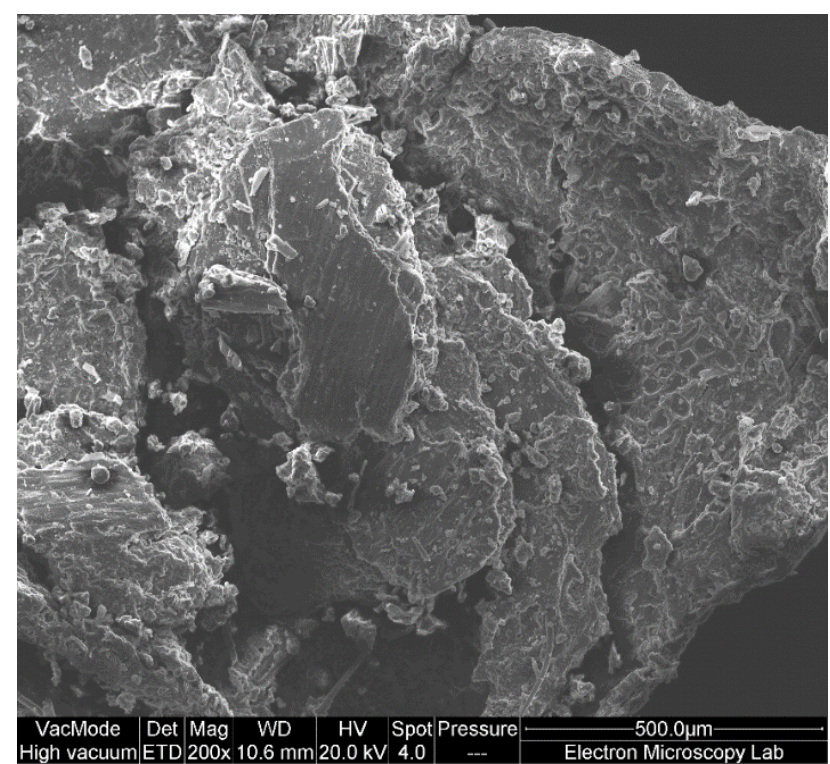

(a)

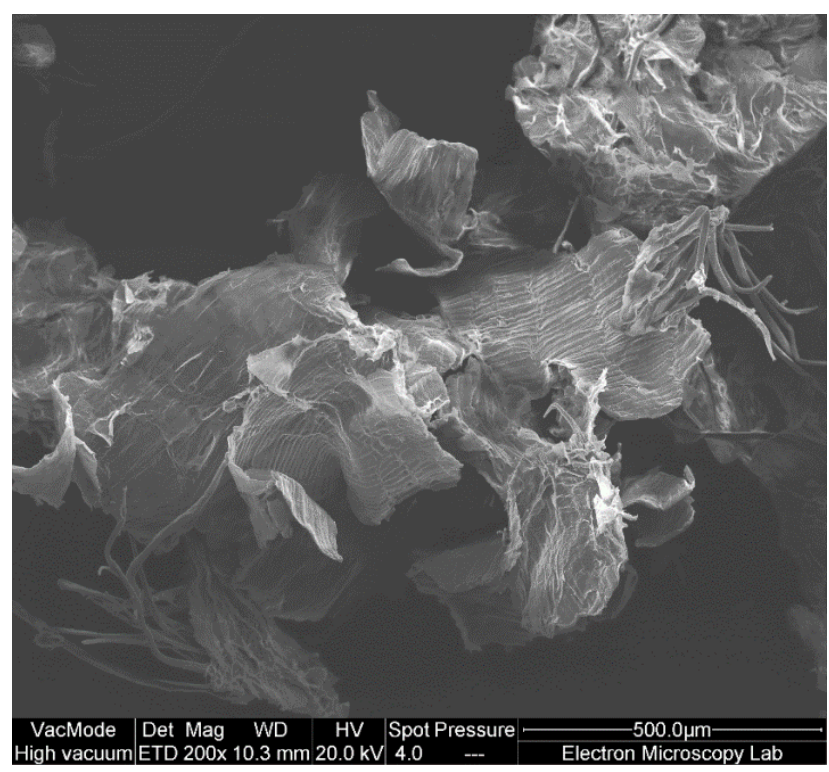

(c)

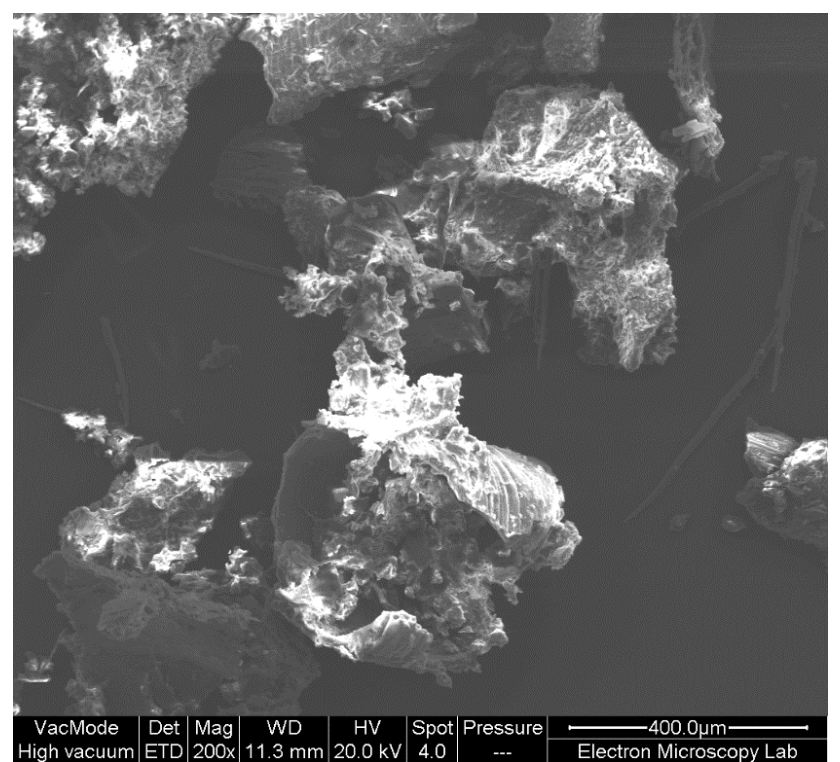

(b)

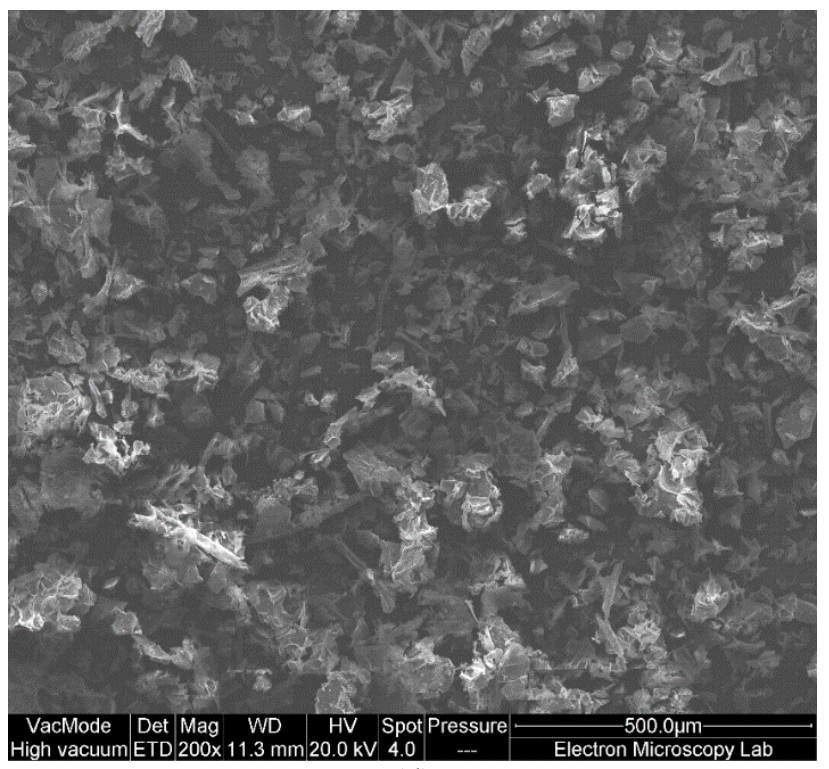

(d)

461 Figure 3: SEM images of: (a) untreated DDGS, (b) untreated DDGS hydrolysed with Accellerase ${ }^{\circledR} 1500$

462 at $1: 0.33$ (mL enzyme : g cellulose), (c) alkaline pretreated $\left(121^{\circ} \mathrm{C} \sim 16 \mathrm{psi}, 15\right.$ minutes, $\left.5 \% \mathrm{NaOH}\right)$ DDGS

463 and (d) alkaline pretreated $\left(121^{\circ} \mathrm{C} \sim 16 \mathrm{psi}, 15\right.$ minutes, $\left.5 \% \mathrm{NaOH}\right)$ DDGS hydrolysed with Accellerase ${ }^{\circledR}$

4641500 at $1: 0.33$ (mL enzyme : g cellulose). 
The changes in functional groups caused by alkaline pretreatment on DDGS were evaluated by Fourier Transform Infrared (FTIR) spectroscopy (Figure 4). A prominent broad peak was observed at a wavelength of $1034 \mathrm{~cm}^{-1}$ in the case of pretreated DDGS solids as opposed to untreated DDGS. A numbers of previous research works assigned this peak to $\mathrm{C}-\mathrm{O}, \mathrm{C}=\mathrm{C}$ and $\mathrm{C}$ -

471 C-O stretching of $\beta-(1,4)$ glycoside bonds in cellulose, hemicellulose and lignin (Maryana et al., 472 2014; Schwanninger et al., 2004; Sills and Gossett, 2012; Xu et al., 2013). This suggests that the 473 increased peak intensity was due to the higher content of cellulose and hemicellulose in pretreated 474 DDGS solids ( $~ 88 \%$ total cellulose and hemicellulose), compared to untreated DDGS ( $\sim 31 \%$ total 475 cellulose and hemicellulose). Similar FTIR data were reported for alkaline treated wheat straw 476 (Asghar et al., 2015) and sugarcane bagasse (Zhang et al., 2013). Moreover, the broad peak centred 477 at $3332 \mathrm{~cm}^{-1}$ in pretreated DDGS solids, which is absent in untreated DDGS, most likely reflects 478 an increased intermolecular hydrogen bonding between the $\beta$-(1,4) glucan chains of cellulose in 479 the sample (Hishikawa et al., 2017); this is line with the higher cellulose content of pretrated DDGS 480 ( 53\%) (Table 2) compared to untreated DDGS (Table 1). In addition, the very small peaks that 481 were present in untreated DDGS at 1598 and $1744 \mathrm{~cm}^{-1}$ are assigned to $\mathrm{C}=\mathrm{O}$ stretching and most 482 likely correspond to the hemicellulose present in DDGS. However, these bands could also be 483 related to the uronic esters and acetyl groups of the ferulic and p-coumaric acids present in lignin 484 (Barman et al., 2012; Schwanninger et al., 2004). The peaks disappeared after pretreatment 485 suggesting that some of hemicellulose or lignin-related compounds were removed during the 486 pretreatment; this coincides with the results in Table 2, where only $17 \%$ xylose and $15 \%$ arabinose 487 were recovered in pretreated DDGS solids. 


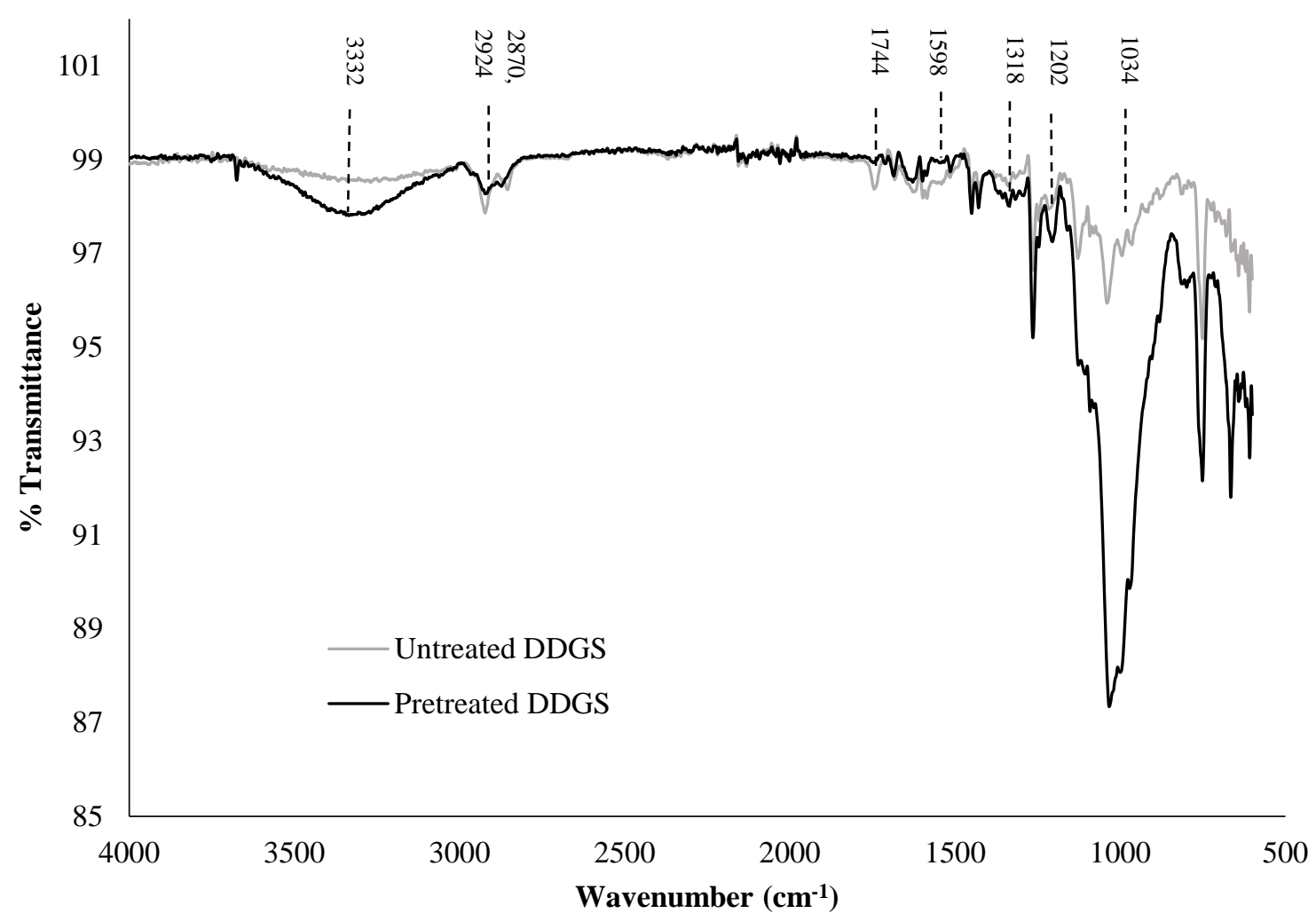

490 Figure 4: FTIR spectra of untreated DDGS and pretreated $\left(121^{\circ} \mathrm{C}, \sim 16 \mathrm{psi}, 15\right.$ minutes, $\left.5 \% \mathrm{NaOH}\right) \mathrm{DDGS}$ 491 solids.

$493 \quad$ 3.5.3 X-ray diffraction (XRD)

494 X-ray diffraction analysis was conducted to assess the effect of crystallinity on the 495 digestibility of DDGS. The obtained XRD spectra were analysed and the results are presented in 496 Table 5. The degrees of crystallinity $\left(X_{c}\right)$ for untreated and pretreated DDGS were different. For 497 untreated DDGS solids, the $X_{c}$ was estimated at 39.7\%, while pretreated DDGS solids had 3 times 498 lower degree of crystallinity, estimated at $13.1 \%$. This was most likely due to the structural changes 499 caused by alkaline pretreatment, more specifically the fact that $\mathrm{NaOH}$ cleaves the ester linkages 
500 between lignin and hemicellulose, which reduces the degree of polymerisation of cellulose and

501 consequently the crystallinity of DDGS (Barman et al., 2012).

502

503 Table 5: Crystalline and amorphous area of untreated and pretreated solids $\left(121{ }^{\circ} \mathrm{C}, \sim 16 \mathrm{psi}, 15\right.$

504 minutes, $5 \% \mathrm{NaOH})$ DDGS

\begin{tabular}{lcc}
\hline \multicolumn{1}{c}{ Substrate } & Untreated DDGS & Pretreated DDGS \\
\hline Crystalline Area & 9409.63 & 1338.27 \\
Amorphous Area & 14272.53 & 8846.83 \\
Degree of crystallinity $\left(X_{c}\right), \%$ & 39.73 & 13.14 \\
\hline
\end{tabular}

$507 \quad 3.6$ Overall mass balance of valorisation process scheme

Figure 5 shows the overall process design based on a alkaline pretreatment process of DDGS 509 with $5 \% \mathrm{NaOH}$ at $121^{\circ} \mathrm{C}(\sim 16 \mathrm{psi})$ for 15 minutes (the best pretreatment condition for obtaining 510 maximum carbohydrate content in the solid fraction), followed by enzymatic hydrolysis of the 511 residual solids using Accelerase $\AA$ 1500, and the mass balances of the key components (sugar 512 monomers reflecting cellulose and hemicellulose, proteins) in the solid and liquid fractions.

513 Untreated DDGS contained $\sim 11 \%$ glucose reflecting the presence of cellulose (the assumption is 514 that the level of $\beta$-glucan is zero), and $\sim 13.7 \%$ xylose and $\sim 6.6 \%$ from arabinose, reflecting the 515 presence of $\sim 20.3 \%$ hemicellulose. DDGS was then subjected to alkaline pretreatment after which $516 \sim 45 \%$ of glucose, $\sim 17 \%$ of xylose and $\sim 15 \%$ of arabinose remained in the recovered solids 517 compared to the starting DDGS material. The majority of the hemicellulose, i.e. $\sim 77 \%$ of xylose 518 and $\sim 100 \%$ of arabinose (although the discrepancy in the arabinose mass balance is noted) and the 
519 majority of the protein $(\sim 79 \%)$ were extracted into the liquid fraction. The enzymatic hydrolysis 520 (using Accelerase ${ }^{\circledR} 1500$ ) of the pretreated DDGS solids led to the recovery of $\sim 87 \%$ of glucose 521 and $\sim 92 \%$ of xylose, indicating the production of a glucose-rich medium. Such medium can be 522 used as a fermentation feedstock for the production of a range of platform or speciality chemicals 523 with high market potential, such as lactic acid and succinic acid, in various industrial sectors (e.g.

524 food, plastics, packaging and chemical sectors). The hemicellulose and protein rich liquid fraction 525 could be further explored. For instance, the liquid fraction can be subjected to ultrafiltration and 526 the isolated protein can be used as starting material for biodegradable films and bioplastics 527 production or as precursor for chemical synthesis (Chatzifragkou et al., 2016; Jones et al., 2015). 528 On the other hand, research on the use of hemicelluloses as materials for edible coating, films or 529 food packaging applications has been reported (Hansen and Plackett, 2008; Xiang et al., 2014) and 530 has led to commercial applications. For example, Xylophane AB have successfully marketed their 531 xylan-based packaging material (Chatzifragkou et al., 2015). Overall, the proposed process scheme 532 recovers the majority of the key DDGS components (cellulose, hemicellulose, proteins) in an 533 efficient manner with relatively low losses, and provides a viable approach for the valorisation of 534 DDGS. 


\section{Pretreatment $\left(121^{\circ} \mathrm{C}, \sim 16 \mathrm{psi}, 15\right.$ minutes, $\left.5 \% \mathrm{NaOH}\right)$}

544

Figure 5: Process scheme and mass balances for the valorisation of DDGS.

\section{Conclusions}

A cellulose-rich solid material was generated from DDGS by alkaline treatment, containing

$559 \sim 88 \%(\mathrm{w} / \mathrm{w})$ of sugars with the majority attributed to the presence of cellulose $(\sim 53 \%)$. The

560 pretreated DDGS solids exhibited significant enzymatic digestibility, leading to 3.6 fold higher

561 glucose concentration compared to untreated DDGS. Approximately $83 \%$ of the hemicellulose and 
$56279 \%$ of the protein present in untreated DDGS were removed during alkaline pretreatment into the

563 liquid fraction. Mass balance analysis of the proposed DDGS valorisation scheme demonstrated

564 that the major DDGS components (cellulose, hemicellulose, proteins) were recovered in the solid

565 and liquid process fractions in an efficient manner.

566

567 Acknowledgments

568

569 The authors would like to acknowledge the Ministry of Higher Education Malaysia (MOHE) and

570 the Universiti Kebangsaan Malaysia, Bangi (UKM), for providing doctoral sponsorship and

571 financial support to carry out this research. Also, our gratitude goes to the staff of the Chemical

572 Analysis Facility (CAF) at the University of Reading for their technical support in conducting the 573 analytical work.

\section{References}

576 Asghar, U., Irfan, M., Iram, M., Huma, Z., Nelofer, R., Nadeem, M., Syed, Q., 2015. Effect of 577 alkaline pretreatment on delignification of wheat straw. Nat. Prod. Res. 29, 125-131.

578 Association of Analytical Communities, 1996. Official Methods of Analysis of AOAC

579 International, 16th ed. AOAC International, Maryland, USA.

580 Badhan, A., Wang, Y., Gruninger, R., Patton, D., Powlowski, J., Tsang, A., McAllister, T., 2014.

581 Formulation of enzyme blends to maximize the hydrolysis of alkaline peroxide pretreated alfalfa

582 hay and barley straw by rumen enzymes and commercial cellulases. BMC Biotechnology 14, 3158331. 
584 Bals, B., Balan, V., Dale, B., 2009. Integrating alkaline extraction of proteins with enzymatic

585 hydrolysis of cellulose from wet distiller's grains and solubles. Bioresour. Technol. 100, 5876586583.

587 Bals, B., Dale, B., Balan, V., 2006. Enzymatic hydrolysis of distiller's dry grain and solubles 588 (DDGS) using ammonia fiber expansion pretreatment. Energy \& Fuels 20, 2732-2736.

589 Barman, D.N., Haque, M.A., Kang, T.H., Kim, M.K., Kim, J., Kim, H., Yun, H.D., 2012. Alkali 590 pretreatment of wheat straw (Triticum aestivum) at boiling temperature for producing a bioethanol 591 precursor. Biosci. Biotechnol. Biochem. 76, 2201-2207.

592 Belyea, R.L., Rausch, K.D., Clevenger, T.E., Singh, V., Johnston, D.B., Tumbleson, M.E., 2010. 593 Sources of variation in composition of DDGS. Anim. Feed. Sci. Technol. 159, 122-130.

594 Bensah, E.C., Mensah, M., 2013. Chemical pretreatment methods for the production of cellulosic 595 ethanol: technologies and innovations. Int. J. Chem. Eng. 2013.

596 Binod, P., Satyanagalakshmi, K., Sindhu, R., Janu, K.U., Sukumaran, R.K., Pandey, A., 2012.

597 Short duration microwave assisted pretreatment enhances the enzymatic saccharification and 598 fermentable sugar yield from sugarcane bagasse. Renewable Energy 37, 109-116.

599 Borges, D.G., Baraldo Junior, A., Farinas, C.S., de Lima Camargo Giordano, R., Tardioli, P.W., 600 2014. Enhanced saccharification of sugarcane bagasse using soluble cellulase supplemented with 601 immobilized $\beta$-glucosidase. Bioresour. Technol. 167, 206-213.

602 Bruynooghe, J., Mackenzi, J., Russell, S., Swift, M.-L., 2013. Wheat DDGS Feed Guide, 1.1 ed. 603 Canadian International Grains Institute (Cigi), Canadian International Grains Institute (Cigi).

604 Burton, E.J., Scholey, D.V., Williams, P.E.V., 2014. Types, properties and processing of bio-based 605 animal feed, in: Waldron, K.W. (Ed.), Advances in Biorefineries: Biomass and Waste Supply 606 Chain Exploitation, First Edition ed. Woodhead Publishing, Cambridge, UK, pp. 771-802. 
607 Chatzifragkou, A., Kosik, O., Prabhakumari, P.C., Lovegrove, A., Frazier, R.A., Shewry, P.R.,

608 Charalampopoulos, D., 2015. Biorefinery strategies for upgrading Distillers' Dried Grains with

609 Solubles (DDGS). Process Biochem. 50, 2194-2207.

610 Chatzifragkou, A., Prabhakumari, P.C., Kosik, O., Lovegrove, A., Shewry, P.R.,

611 Charalampopoulos, D., 2016. Extractability and characteristics of proteins deriving from wheat

612 DDGS. Food Chem. 198, 12-19.

613 Chen, Y., Stevens, M.A., Zhu, Y., Holmes, J., Xu, H., 2013. Understanding of alkaline

614 pretreatment parameters for corn stover enzymatic saccharification. Biotechnol. Biofuels. 6, 8.

615 Cozannet, P., Primot, Y., Gady, C., Métayer, J.P., Callu, P., Lessire, M., Skiba, F., Noblet, J., 2010.

616 Ileal digestibility of amino acids in wheat distillers dried grains with solubles for pigs. Anim. Feed.

617 Sci. Technol. 158, 177-186.

618 da Silva, G.T., Chiarello, L.M., Lima, E.M., Ramos, L.P., 2016. Sono-assisted alkaline 619 pretreatment of sugarcane bagasse for cellulosic ethanol production. Catalysis Today 269, 21-28.

620 Dien, B.S., Ximenes, E.A., O'Bryan, P.J., Moniruzzaman, M., Li, X.-L., Balan, V., Dale, B., Cotta,

621 M.A., 2008. Enzyme characterization for hydrolysis of AFEX and liquid hot-water pretreated

622 distillers' grains and their conversion to ethanol. Bioresour. Technol. 99, 5216-5225.

623 Dodd, D., Cann, I.K.O., 2009. Enzymatic deconstruction of xylan for biofuel production. Global 624 change biology. Bioenergy 1, 2-17.

625 Gao, D., Chundawat, S.P.S., Sethi, A., Balan, V., Gnanakaran, S., Dale, B.E., 2013. Increased 626 enzyme binding to substrate is not necessary for more efficient cellulose hydrolysis. Proceedings

627 of the National Academy of Sciences of the United States of America 110, 10922-10927. 
628 Han, J., Liu, K., 2010. Changes in Composition and Amino Acid Profile during Dry Grind Ethanol

629 Processing from Corn and Estimation of Yeast Contribution toward DDGS Proteins. J. Agric. Food

630 Chem. 58, 3430-3437.

631 Han, L., Feng, J., Zhang, S., Ma, Z., Wang, Y., Zhang, X., 2012. Alkali pretreated of wheat straw

632 and its enzymatic hydrolysis. Braz. J. Microbiol. 43, 53-61.

633 Hansen, N.M.L., Plackett, D., 2008. Sustainable Films and Coatings from Hemicelluloses: A

634 Review. Biomacromolecules. 9, 1493-1505.

635 Hishikawa, Y., Togawa, E., Kondo, T., 2017. Characterization of Individual Hydrogen Bonds in

636 Crystalline Regenerated Cellulose Using Resolved Polarized FTIR Spectra. ACS Omega 2, 14696371476.

638 Hsu, T.C., Guo, G.L., Chen, W.H., Hwang, W.S., 2010. Effect of dilute acid pretreatment of rice 639 straw on structural properties and enzymatic hydrolysis. Bioresour. Technol. 101.

640 Hu, J., Arantes, V., Saddler, J., 2011. The enhancement of enzymatic hydrolysis of lignocellulosic

641 substrates by the addition of accessory enzymes such as xylanase: is it an additive or synergistic

642 effect? Biotechnol. Biofuels. 4, 1-14.

643 Jones, A., Mandal, A., Sharma, S., 2015. Protein-based bioplastics and their antibacterial potential.

644 J. Appl. Polym. Sci. 132.

645 Jönsson, L.J., Martín, C., 2016. Pretreatment of lignocellulose: Formation of inhibitory by646 products and strategies for minimizing their effects. Bioresour. Technol. 199, 103-112.

647 Kim, I., Han, J.-I., 2012. Optimization of alkaline pretreatment conditions for enhancing glucose 648 yield of rice straw by response surface methodology. Biomass Bioenergy 46, 210-217.

649 Kim, J.S., Lee, Y.Y., Kim, T.H., 2016. A review on alkaline pretreatment technology for 650 bioconversion of lignocellulosic biomass. Bioresour. Technol. 199, 42-48. 
651 Kim, T.H., Taylor, F., Hicks, K.B., 2008a. Bioethanol production from barley hull using SAA

652 (soaking in aqueous ammonia) pretreatment. Bioresour. Technol. 99, 5694-5702.

653 Kim, Y., Hendrickson, R., Mosier, N., Ladisch, M., 2009. Liquid Hot Water Pretreatment of

654 Cellulosic Biomass, in: Mielenz, J.R. (Ed.), Biofuels. Humana Press, pp. 93-102.

655 Kim, Y., Hendrickson, R., Mosier, N.S., Ladisch, M.R., Bals, B., Balan, V., Dale, B.E., 2008b.

656 Enzyme hydrolysis and ethanol fermentation of liquid hot water and AFEX pretreated distillers'

657 grains at high-solids loadings. Bioresour. Technol. 99, 5206-5215.

658 Knill, C.J., Kennedy, J.F., 2003. Degradation of cellulose under alkaline conditions. Carbohydrate

659 Polymers 51, 281-300.

660 Kumar, R., Wyman, C.E., 2009. Effect of xylanase supplementation of cellulase on digestion of 661 corn stover solids prepared by leading pretreatment technologies. Bioresource Technol 100.

662 Liu, K., 2011. Chemical composition of distillers grains, a review. J. Agric. Food Chem. 59, 15086631526.

664 Maryana, R., Ma'rifatun, D., Wheni, A., Satriyo, K., Rizal, W.A., 2014. Alkaline pretreatment on 665 sugarcane bagasse for bioethanol production. Energy Procedia 47, 250-254.

666 McIntosh, S., Vancov, T., 2011. Optimisation of dilute alkaline pretreatment for enzymatic 667 saccharification of wheat straw. Biomass Bioenergy 35, 3094-3103.

668 Moreau, R.A., Nghiem, N.P., Rosentrater, K.A., Johnston, D.B., Hicks, K.B., 2012. Ethanol 669 Production from Starch-Rich Cropss Other than Corn and the Composition and Value of Resulting 670 DDGS, in: Liu, K., Rosentrater, K.A. (Eds.), Distillers Grain: Production, Properties, and 671 Utilization. CRC Press: Taylor \& Francis Group, Boca Rato, FL, pp. 103 - 117. 
672 Mosier, N., Wyman, C., Dale, B., Elander, R., Lee, Y.Y., Holtzapple, M., Ladisch, M., 2005.

673 Features of promising technologies for pretreatment of lignocellulosic biomass. Bioresource 674 Technol 96.

675 Nuez Ortín, W.G., Yu, P., 2009. Nutrient variation and availability of wheat DDGS, corn DDGS 676 and blend DDGS from bioethanol plants. J. Sci. Food Agric. 89, 1754-1761.

677 Pedersen, M.B., Dalsgaard, S., Knudsen, K.E.B., Yu, S., Lærke, H.N., 2014. Compositional profile 678 and variation of Distillers Dried Grains with Solubles from various origins with focus on non679 starch polysaccharides. Anim. Feed. Sci. Technol. 197, 130-141.

680 Pisupati, S.V., Tchapda, A.H., 2015. Thermochemical Processing of Biomass, in: Ravindra, V. 681 (Ed.), Advances in Bioprocess Technology. Springer International Publishing, pp. 277-314.

682 Rabelo, S.C., Amezquita Fonseca, N.A., Andrade, R.R., Maciel Filho, R., Costa, A.C., 2011. 683 Ethanol production from enzymatic hydrolysis of sugarcane bagasse pretreated with lime and 684 alkaline hydrogen peroxide. Biomass Bioenergy 35, 2600-2607.

685 Schwanninger, M., Rodrigues, J., Pereira, H., Hinterstoisser, B., 2004. Effects of short-time 686 vibratory ball milling on the shape of FT-IR spectra of wood and cellulose. Vibrational 687 Spectroscopy 36, 23-40.

688 Sills, D.L., Gossett, J.M., 2012. Using FTIR to predict saccharification from enzymatic hydrolysis 689 of alkali-pretreated biomasses. Biotechnol. Bioeng. 109, 353-362.

690 Sluiter, A., Hames, B., Ruiz, R., Scarlata, C., Sluiter, J., Templeton, D., Crocker, D., 2011. 691 Determination of Structural Carbohydrates and Lignin in Biomass, Laboratory Analytical 692 Procedures (LAP) for Standard Biomass Analysis. National Renewable Energy Laboratory 693 (NREL). 
694 Subhedar, P.B., Gogate, P.R., 2014. Alkaline and ultrasound assisted alkaline pretreatment for

695 intensification of delignification process from sustainable raw-material. Ultrason. Sonochem. 21, $696 \quad 216-225$.

697 Villegas-Torres, M.F., Ward, J.M., Lye, G.J., 2015. The protein fraction from wheat-based dried 698 distiller's grain with solubles (DDGS): extraction and valorization. N. Biotechnol. 32, 606-611.

699 Wan, C., Zhou, Y., Li, Y., 2011. Liquid hot water and alkaline pretreatment of soybean straw for 700 improving cellulose digestibility. Bioresour. Technol. 102, 6254-6259.

701 Widyaratne, G.P., Zijlstra, R.T., 2007. Nutritional value of wheat and corn distiller's dried grain 702 with solubles: Digestibility and digestible contents of energy, amino acids and phosphorus, 703 nutrient excretion and growth performance of grower-finisher pigs. Can. J. Anim. Sci. 87, 103704114.

705 Xiang, Z., Watson, J., Tobimatsu, Y., Runge, T., 2014. Film-forming polymers from distillers’ 706 grains: structural and material properties. Ind. Crops Prod. 59, 282-289.

707 Xu, F., Yu, J., Tesso, T., Dowell, F., Wang, D., 2013. Qualitative and quantitative analysis of 708 lignocellulosic biomass using infrared techniques: A mini-review. Appl. Energy 104, 801-809.

709 Xu, J., Cheng, J.J., Sharma-Shivappa, R.R., Burns, J.C., 2010. Sodium Hydroxide Pretreatment of 710 Switchgrass for Ethanol Production. Energy \& Fuels 24, 2113-2119.

711 Xu, Y., Hanna, M.A., 2010. Optimum conditions for dilute acid hydrolysis of hemicellulose in 712 dried distillers grains with solubles. Ind. Crops Prod. 32, 511-517.

713 Yang, J., Zhang, X., Yong, Q., Yu, S., 2011. Three-stage enzymatic hydrolysis of steam-exploded 714 corn stover at high substrate concentration. Bioresour. Technol. 102, 4905-4908.

715 Yin, S., Tan, Z., 2012. Hydrothermal liquefaction of cellulose to bio-oil under acidic, neutral and 716 alkaline conditions. Appl. Energy 92, 234-239. 
717 Zhang, A.-P., Liu, C.-F., Sun, R.-C., Xie, J., 2013. Extraction, purification, and characterization 718 of lignin fractions from sugarcane bagasse. BioResources 8, 1604-1614.

719 Zhao, X., Peng, F., Cheng, K., Liu, D., 2009. Enhancement of the enzymatic digestibility of 720 sugarcane bagasse by alkali-peracetic acid pretreatment. Enzyme. Microb. Technol. 44, 17-23.

721 Zhao, X., Zhang, L., Liu, D., 2012. Biomass recalcitrance. Part I: the chemical compositions and 722 physical structures affecting the enzymatic hydrolysis of lignocellulose. Biofuels, Bioprod. 723 Biorefin. 6, 465-482.

724 Zhou, D., Zhang, L., Guo, S., 2005. Mechanisms of lead biosorption on cellulose/chitin beads. 725 Water Research 39, 3755-3762. 